\title{
Implementation of the Banten North Coastal Rehabilitation Policy
}

\author{
Ardiyansah $^{1}$, Endang Larasati ${ }^{2}$ \\ \{ardi1410@students.undip.ac.id ${ }^{1}$ \} \\ Universitas Diponegoro, Indonesia ${ }^{1,2}$
}

\begin{abstract}
The people of the northern coast of Banten found a lump of crude oil from an oil refinery spill at PT. Pertamina in the northern waters of Karawang. This study aims to describe the implementation of the policy of the Regulation of the Minister of Maritime Affairs and Fisheries of the Republic of Indonesia Number 24 of 2016 concerning Procedures for Rehabilitation of Coastal Areas and Small Islands. The results showed that the implementation of rehabilitation activities was to identify the cause of the damage, identify the level of damage, and prepare a rehabilitation plan and the policy objectives were to clean up the coastal area and to restore mangrove plants. Resources on fund resources are sourced from the budget of PT. Pertamina and the State Budget through the Ministry of Maritime Affairs and Fisheries, while the human resources involved are officers appointed by Pertamina who are paid by Pertamina to clean up oil spills. Communication program implementers have been made to Pertamina to work together to rehabilitate and also discuss compensation given to fishermen and surrounding communities. Characteristics of implementing agencies that the implementer understands well what are the objectives and responsibilities in each task. Then the social condition of the coastal area rehabilitation policy is the community asking PT. Pertamina to be transparent in relation to operational failures, while the economic conditions that affect are ecological and economic losses that occur and cause income to decline, even none. Whereas the political condition resulting from pollution of coastal areas is that the Central Government continues to encourage the Provincial Government to immediately complete the regional regulation on zoning plans for coastal areas and small islands.
\end{abstract}

Keywords: Policy Implementation, Rehabilitation of the North Coastal Region of Banten.

\section{Introduction}

Indonesia is an archipelago that has a very large number of islands. 2013 SLHI data released by the Ministry of Environment, the number of islands in Indonesia is 13,466 islands with a coastline of $80,791 \mathrm{~km}$. Indonesia has enormous opportunities and challenges in developing and managing the potential of coastal and marine resources. Indonesia's coastal and marine areas have enormous natural resources and provide diverse environmental services, such as oil and gas, minerals, fisheries, coral reef and mangrove ecosystems, as well as tourism. However, resources in Indonesia's coastal and marine areas in the past have not received as much serious attention as development in the mainland, especially in Indonesia's major cities.

Most major cities in Indonesia are located in coastal areas. The cities are growing rapidly as other big cities in the world over the times. In the beginning, the existence and development of a city in a coastal area cannot be separated from its function as an area or region which is an 
access that connects the land area (inland) with the outside world. However, in its development the cities did not only develop as access areas, but in accordance with the diversity of functions, such as administrative areas and as centers of industrial trade, services and so on (Hantoro, 2008). This is evidenced by the increasing number of Indonesian fishermen from year to year.

Table 1. Number of Fishermen at Sea in 2014-2016

\begin{tabular}{|c|c|c|}
\hline No & Year & Number of Indonesian Fishermen \\
\hline 1 & 2014 & 2.210 .195 \\
\hline 2 & 2015 & 2.275 .139 \\
\hline 3 & 2016 & 2.265 .859 \\
\hline
\end{tabular}

Source: www.bps.go.id (statistics of marine and coastal resources).

While the number of fishermen in Banten is explained through in the table 2.

Table 2. Number of fishermen Banten in 2012-2014

\begin{tabular}{|c|c|c|}
\hline No & Year & Number of Banten Fishermen \\
\hline 1 & 2012 & 1.405 \\
\hline 2 & 2013 & 1.437 \\
\hline 3 & 2014 & 1.437 \\
\hline \multicolumn{2}{|c|}{ Source: www.bps.go.id (statistics of marine and coastal resources) } \\
\hline
\end{tabular}

The rapid development of coastal cities in addition to providing economic benefits also raises various problems such as the existence of environmental impacts. According to CicinSain and Knecht (1998), intensive spatial use of coastal areas that have resulted in exceeding the carrying capacity or sustainable capacity of ecosystems, coastal areas, such as pollution, overfishing, physical degradation of habitats and coastal abrasion especially in coastal areas that are densely populated and high level of development.

Some development activities in land and sea areas, many of which still have a negative impact on the environment which ultimately results in decreased quality of the coastal and marine environment and the preservation of natural resources, namely in the form of pollution and environmental damage. The most common environmental pollution in Indonesian waters is pollution from oil spills. There are at least 36 cases of pollution of coastal areas by oil spills in Indonesian waters from 1999 to 2018 , this is explained in the table below.

Table 3. Incidence of Oil Spills in Indonesian Waters, 1999-2018

\begin{tabular}{|c|c|l|l|}
\hline No & Years & \multicolumn{1}{|c|}{ Location } & \multicolumn{1}{c|}{ The Incident } \\
\hline 1. & 1999 & Batam & Mighty Serent II, sink, leftover oil \\
\hline 2. & 1999 & Tanjung Priok & Pertamina Supply OS. 27, residual oil spills \\
\hline 3. & 1999 & Sungai Siak Riau & MT. Stephanie XVII, premium collision \\
\hline 4. & 1999 & Cilacap & MT. King Fisher torn (640 thousand liters spilled) \\
\hline 5. & 2000 & Cilacap & KM. HHC sinks (9,000 tons of asphalt) \\
\hline 6. & 2000 & Batam & MT. Natuna Sea Kandas (4,000 tons of oil) \\
\hline 7. & 2001 & Tegal, Cirebon & Steadfast sink (1,200 tons of waste oil) \\
\hline 8. & 2002 & Bengkalis Riau & TKG Bumindo, kandas, MFO \\
\hline 9. & 2004 & Wiriagar & TK-OSC 10, sink, crude oil \\
\hline 10. & 2004 & Wilayah TSS & MV. Kamimasen Hyundai, tongkang cargo oil collision \\
\hline 11. & 2004 & Santuriang & Tanker MT. Pan Sejati, sink, oil \\
\hline 12. & 2004 & Teluk Tomini & Tanker MT. Istana VII, sink, oil \\
\hline 13. & 2004 & Balikpapan & Tanker MT. Panos 6 leak oil \\
\hline 14. & 2004 & Teluk Tomini & Tanker MT. North Star, sink oil \\
\hline
\end{tabular}




\begin{tabular}{|c|c|c|c|}
\hline 15. & 2004 & $\begin{array}{l}\text { Tanjung } \\
\text { Karimun }\end{array}$ & Tanker MT. Vista Mariner, kandas oil \\
\hline 16. & 2004 & Pekanbaru & Tanker MT. Maulana, burning, oil \\
\hline 17. & 2004 & Cilacap & Tanker MT. Lucky Lady, leak, oil \\
\hline 18. & 2004 & Batu Ampar Batam & KM. Swadaya Lestari, dirty oil \\
\hline 19. & 2004 & Ambon & Tanker MT. PJST 03/YB 9043, burning, solar \\
\hline 20. & 2005 & Teluk Ambon & The explosion of a fishing boat MV Fu Yuan Fu F66 \\
\hline 21. & 2008 & Semarang & MT. Kharisma Selatan upside down 500 kilo liter MFO \\
\hline 22. & 2009 & Laut Timur, NTT & Explosion of oil fields Montara (Refinery PTTEP Australia) \\
\hline 23. & 2009 & Gresik & $\begin{array}{l}\text { PT. Armada Hess Indonesia Pangkah, Liquid Carbon Hydro } \\
\text { Oil }\end{array}$ \\
\hline 24. & 2010 & Tanjung Perak & MV. Traveller Biglift leak out 200 ton \\
\hline 25. & 2010 & Cilacap & Leakage of MFO oil filling into MT Asia tanker 17 \\
\hline 26. & 2011 & Blora & $\begin{array}{l}\text { The theft of a } 4 \text { meter pipe which is a } 4 \text { inch trunklin between } \\
\text { Nglobo and Cepu }\end{array}$ \\
\hline 27. & 2011 & Dumai & The spill of tens of tons of CPO from the storage tank \\
\hline 28. & 2012 & Cilacap & Oil spill around the Sleko pier to a radius of 200 meters \\
\hline 29. & 2014 & Perairan Dumai Riau & Oil spill in KCPI Dumai oil port of Medelyn West Vessel \\
\hline 30. & 2015 & Tuban & PT offshore oil pipeline leak. PetroChina \\
\hline 31. & 2015 & Nusakambangan & $\begin{array}{l}\text { Underwater oil pipeline leak PT. Pertamina Refinery Unit IV } \\
\text { Cilacap }\end{array}$ \\
\hline 32. & 2015 & Teluk Penyu, Cilacap & $\begin{array}{l}\text { Oil spill from the MT Martha Petrol that was caught by the } \\
\text { reef }\end{array}$ \\
\hline 33. & 2016 & Dumai & $\begin{array}{l}\text { Crude Palm Oil Timbu Tank Spill (CPO) PT. Nagamas } \\
\text { Palmoil Lestari in Pelindo Dumai Area }\end{array}$ \\
\hline 34. & 2016 & Malang & Crude oil spills in the waters of South Malang \\
\hline 35. & 2017 & Padang & $\begin{array}{l}\text { PFAD type CPO oil spill from PT. Wira Innomas around } 50 \\
\text { tons }\end{array}$ \\
\hline 36. & 2018 & $\begin{array}{ll}\text { Teluk } & \text { Balikpapan, } \\
\text { Kaltim } & \end{array}$ & $\begin{array}{l}\text { Pollution of crude oil waste originating from one of the oil } \\
\text { pipes from the Lawe-lawe Pertamina refinery that broke up } \\
\text { in the middle of the Balikpapan bay }\end{array}$ \\
\hline
\end{tabular}

In 2019 one of the regions in Indonesia that felt the impact of damage to the coastal environment due to oil spills was the Lontar beach area of Brambang village, Lontar Village, Tirtayasa District, Serang Regency or in the northern coastal area of Banten. In July 2019 the people of Banten's north coast discovered many lumps of crude oil in the waters of the area. Clumps of oil that resemble goat droppings were originally found in the ecotourism area of the mangrove forest in the tourist area of the Rainbow Bridge.

The crude oil lumps came from PT. Pertamina in the northern waters of Karawang. The oil leak and gas bubble came from the YYA offshore platform, PT. Pertamina's Offshore North West Java (ONWJ) oil block. The impact of scattered crude oil clumps includes the number of fish, marine animals, and mangrove trees that have died, and the crude oil lump has now begun to enter the fish and shrimp ponds owned by local residents.

The impact of the oil refinery leakage in the Karawang north coast region not only had an impact on environmental damage on the north coast of Banten, but the north coast of Jakarta was also threatened by the impact of the oil refinery leakage. According to the Section of Supervision and Control of the Impact of Environmental Pollution and Cleanliness of the North Jakarta Environmental Department, the radius of oil pollution is still detected in the Thousand Islands, although it has not yet extended to the other three districts in North Jakarta. However, 
this is still a worrying thing if the lump of crude oil is carried by the ocean currents which are affected by coastal winds.

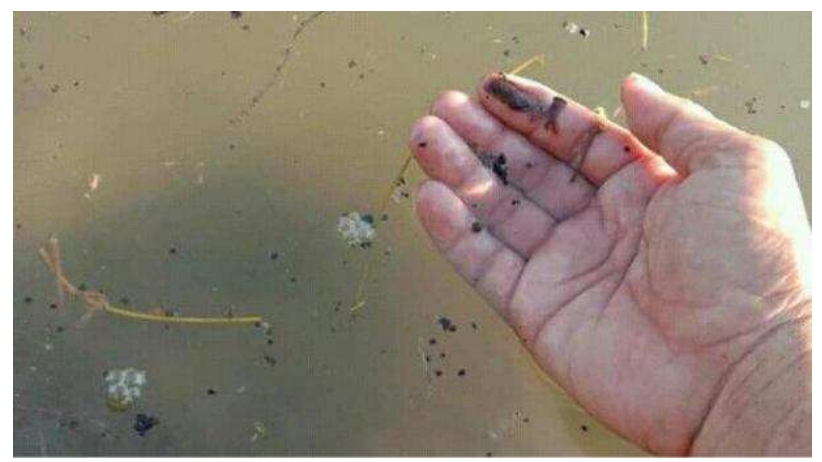

Fig. 1. Crude oil lumps are in the Lontar Coast region [1].

Based on this, researchers are interested in conducting a study entitled Implementation of the Banten North Coastal Rehabilitation Policy. This study aims to describe the implementation of the policy of the Regulation of the Minister of Maritime Affairs and Fisheries of the Republic of Indonesia Number 24 of 2016 concerning Procedures for Rehabilitation of Coastal Areas and Small Islands. Implementation of public policy is said to be a process because in it there are activities, according to Sabatier and Mazmanian [2] said that policy implementation is activities that occur after the issuance of orders from the authority of public policy makers including efforts both from the aspect of implementing and its substantive impact on the people.

\section{Method}

The method used in this research is descriptive qualitative method. This research is presented using a narrative that illustrates how the implementation of the rehabilitation policy on coastal areas and small islands and what obstacles are found in the implementation of the Minister of Maritime Affairs and Fisheries Regulation No. 24 of 2016 concerning the procedures for rehabilitation of coastal areas and small islands. The data were obtained from informants who were determined by purposive sampling. Data were analyzed using an interactive model related to the process by which policy was implemented by phasing the analysis: data reduction, data presentation and drawing conclusions.

\section{Theoretical Framework}

\subsection{Public Policy}

To answer what is the problem according to Amara Raksasataya [3] also stated that "public policy as a tactic and strategy directed to achieve a goal". Therefore, a policy contains 3 (three) important elements, namely: a) Identification of the objectives to be achieved; b) Tactics or strategies of various steps to achieve the desired goals; (c) Provision of various inputs to enable actual implementation. 
After finding a solution the problem then the implementers to run and solve the problem must carry out what is the goal, as stated by James Anderson [4] provides an understanding of the definition of public policy in his book Public Policy Making, as The following "series of activities that have a specific purpose / goal which is followed and carried out by an actor or group of actors relating to an issue or an issue of concern".

\subsection{Policy Implementation}

Van Meter and Van Horn [5] explain that policy implementation, as an action taken either by individuals or government officials or private groups or groups directed towards the achievement of the objectives outlined in the policy decision. There are five variables that affect the performance of policy implementation. The five variables are as follows: (1) Policy standards and objectives; (2) Resources; (3) Communication between organizations and strengthening activities; (4) Characteristics of implementing agencies; (5) Social, economic and political conditions [6].

These five things are important to be prepared so that what is the goal of implementing the policy can be implemented well. After the policy is implemented the evaluation process must also be made so that what is the purpose of the policy can be seen. As stated by [7]. A policy after it is implemented needs to be evaluated so that what knows whether the policy is right on target or not in accordance with what is needed by the community. According to [7] Policy evaluation is carried out to find out 4 (four) aspects, namely: 1) Process of policy making, 2) Process of policy implementation, 3) Consequences of policy, 4) Effectiveness of policy.

\section{Result and Discussion}

\subsection{Implementation of the Banten North Coastal Rehabilitation Policy}

In the practice of carrying out rehabilitation in the northern coast of Banten, conditions in the field indicate that not all policy implementers understand well how the procedures and procedures for rehabilitation of environmental damage occur. This can cause a policy not to run well.

Implementation of policies is an important thing in implementing policies that have been made, because where one of the determining factors in achieving good results from a policy is the implementer. Policy implementation is the implementation of basic policy decisions both in the form of laws, orders or decisions made by the executive.

Another problem arising from the rehabilitation policy of the northern coast of Banten is that the community does not yet understand the rehabilitation procedures and procedures. This is because the Central and Regional Governments have not provided maximum education related to rehabilitation procedures. According to representatives from the Ministry of the Environment, his office has conducted education to the public regarding the prevention of dangerous actions such as littering cigarettes around the oil spill area.

Amara Raksasataya [3] also suggested that "public policy as a tactic and strategy directed towards achieving a goal". Therefore, a policy contains 3 elements, namely: a) Identification of the objectives to be achieved; b) Tactics or strategies of various steps to achieve the desired goals; c) Provision of various inputs to enable actual implementation. 
In public policy, in addition to having objectives, tactics and strategies for achieving it, it is also necessary that what is desired is achieved well, therefore in implementing a public policy it is necessary to prepare a variety of ways including making a procedure in the service must be qualified so that it is easy to understand so people can understand well what is the goal of a government policy.

\subsection{Obstacles to Policy Implementation}

Van Metter and Van Horn [6] mention there are five variables that affect the performance of policy implementation. The five variables are as follows: a) Policy standards and objectives; b) Resources; c) Communication between organizations and strengthening activities; d) Characteristics of implementing agencies; e) Social, economic and political conditions.

From the aspect of standard and policy objectives in a policy has a standard and policy objective that must be achieved, concerning the rehabilitation of the northern coast of Banten. Based on the results of research on the Minister of Maritime Affairs and Fisheries Regulation No. 24 of 2016 has the goal that rehabilitation is carried out if the use of coastal areas and small islands results in damage to Ecosystems or fish populations that exceed the criteria of damage to ecosystems/fish populations. Policies are government actions that are designed to achieve a number of results.

In a policy made by the government, it is necessary to calculate whether a policy is in accordance with what is needed by the community. Therefore, from that in a policy making process needs to be considered not only in terms of how to implement it, but also need to consider whether in the formulation process, according to what is needed.

Then the researchers formulate the impact that occurs both expected and unexpected (success/failure). Then it can be concluded that the expected impact is that marine ecosystems and marine plants can be rehabilitated as before, so that fishermen and communities around the coast don't lose their livelihoods. Based on the research results it is known that the impact of policies made by the government through the Minister of Maritime Affairs and Fisheries Regulation is very good, because the community has legal certainty related to the rehabilitation of coastal areas and small islands affected by environmental pollution. Another impact arising from the implementation of the rehabilitation policy on coastal areas and small islands is that the public complained about the preventive efforts of industrial activities around the coastal area, meaning that the rehabilitation activities were not followed by a Regional Regulation governing mining and construction activities that were not in accordance with ecological principles.

\subsection{Policy Standards and Targets}

To achieve the standards and objectives of the policy, clear operational procedures for standards are needed. In the context of carrying out rehabilitation of coastal areas according to the Minister of Maritime Affairs and Fisheries Regulation No. 24 of 2016 it is explained that rehabilitation activities are carried out through several activities including identification of the causes of damage, identification of the extent of damage, and preparation of rehabilitation plans. In this case, PT. Pertamina itself has made several efforts in order to rehabilitate coastal areas affected by leakage, including replanting and cleaning up mangrove ecosystems in coastal areas. The mangrove restoration is planned to be carried out in three main affected areas, namely in West Java, DKI Jakarta and Banten. The location was determined based on a survey of the Bogor Institute of Agriculture (IPB), the Ministry of Environment \& Forestry (KLHK), and the 
Department of Environment of the region. In addition, Pertamina continues to make efforts to close wells by drilling relief wells or new wells to drain wells that have leaks. The event of the leakage of the ONWJ YYA-1 well has been going on for around 3 months.

The policy objective is basically what the program or policy wants to achieve, whether tangible or not, short, medium or long term. Clarity and policy objectives must be seen specifically so that at the end of the program the success or failure of the policy or program being carried out can be known. The objectives of the rehabilitation policy of the northern coastal area of Banten are to clean up the coastal area from crude oil spills and to restore mangrove plants. In addition to rehabilitation, the objective of the rehabilitation policy for coastal areas and other small islands is to encourage the provincial government to immediately make a Regional Regulation on the Zoning Plan for Coastal Areas and Small Islands as a form of preventive measures for mining activities around the coastal area.

\subsection{Resource}

Based on the findings of researchers in the field, it is known that the implementation of the rehabilitation of coastal areas with funding sources comes from the budget of PT. Pertamina as the party which is fully responsible for the leakage of crude oil spills that pollutes the northern coast of Banten, and other sources through the State Budget and Revenue through the Ministry of Maritime Affairs and Fisheries of the Republic of Indonesia.

Another obstacle encountered by researchers in the field is the lack of human resources and supporting tools in the field. Human resources deployed to clean up oil spills are officials appointed by Pertamina and the community who go down to the water and collect waste spills collected in sacks up to at least 10 kilograms will receive a wage of Rp 100,000 by Pertamina. In a policy that is made if it is not supported by the two things mentioned above, the policy cannot run properly. Resources are also important in implementing policies, both human resources and non-human resources, because they support the successful implementation of policies.

\subsection{Communication between Organizations and Strengthening Activities}

In the process of rehabilitating the northern coast of Banten, in this case the Ministry of Maritime Affairs and Fisheries and the Regional Government as the program implementers have communicated to Pertamina to cooperate in rehabilitating the northern coast of Banten affected by crude oil spills. The communication not only discussed rehabilitation activities but also discussed compensation given to fishermen and surrounding communities affected by environmental pollution.

The Ministry of Maritime Affairs and Fisheries has conducted data collection on residents affected by pollution on August 15-18, 2019 in the Karawang and Bekasi regions, West Java and Banten. KKP data that has been uploaded to the system as of August 28, 2019 is as many as 14,721 people. The data was further verified on 2-9 September 2019 in each district and city by the compensation team determined through the Decree of the Regent and Mayor of each region. For initial compensation, an agreement of Rp. 900,000 per citizen every month, which is for two months in the affected period, namely July to August 2019. 


\subsection{Characteristics of Implementing Agencies}

The findings of researchers in the field related to this include the implementation of rehabilitation of coastal areas in the Central Government, in this case the Ministry of Maritime Affairs and Fisheries gives confidence to Pertamina to take full responsibility for efforts to clean up coastal areas from oil spills, in this regard Pertamina has sought to provide a response well as soon as possible to clean up and rehabilitate efforts to coastal areas affected by pollution, but there are some things that become obstacles in rehabilitation of coastal areas, namely the limitations on human resources and supporting tools in carrying out cleaning. Then the other thing that becomes a finding that is about cognition is the understanding of the implementer of the policy, it can be explained that the implementer understands well what are the objectives and responsibilities in each task and job that has been given. Regarding the value preferences held by the policy implementing body based on the results of the study, it can be seen that the value that is used as a reference in implementing the policy is the value of compliance with the applicable laws and regulations, so that the law becomes a guideline in the implementation of the policy.

\subsection{Social, Economic and Political Conditions}

Based on the results of the study of social conditions, the economy affects the achievement of the objectives of a policy, where the policy made has a target / target of the problem to be solved, but the problem arises from the implementation of the policy is that there are still people asking PT. Pertamina's transparency regarding the YYA-1 well is known to have experienced operational failure and uncontrolled blow out, which caused oil spills since July 12, 2019 in the waters off the Karawang coast. Until now, several civil societies have sent two requests for information to Pertamina to open the complete YYA-1 well data.

Economic conditions that occur due to pollution of the area are in addition to fishermen who are the main victims of the oil spill event, fish breeders who have floating net cages (KJA) or fishponds around the location of the incident are also the most disadvantaged parties. Ecological and economic losses are estimated and this will take a long time to recover. Thousands of fishermen were forced to stop forcibly looking for fish and this caused income to decline, even none. Many fish and shrimp die from oil spills that pollute sea water. The number of fish and other marine biota that died, because the waste oil has spread far into the ocean, it makes the fish caught by fishermen also has the potential to contain contaminated waste. Therefore, the surrounding community who are accustomed to buying fish from coastal areas in the pollution location do not buy fish caught by local fishermen.

The political condition resulting from the pollution of coastal areas is that the Central Government continues to encourage the Provincial Government to immediately complete the regional zoning regulations on coastal zones and small islands (RZWP3K) as soon as possible. Until now, out of 34 provinces, 21 provinces have stipulated RZWP3K Perda, 1 province has been evaluated by the Ministry of Home Affairs, 1 province is under discussion in the DPRD, and 11 provinces are still in the process of completing RZWP3K documents. Among the 21 provinces that have RZWP3K Regional Regulations, are North Sumatra, West Sumatra, Lampung, West Java, Central Java, East Java, DIY, West Kalimantan, Central Kalimantan, North Kalimantan, South Kalimantan, NTB, NTT, West Sulawesi, Southeast Sulawesi, Central Sulawesi, Gorontalo, North Sulawesi, South Sulawesi, Maluku and North Maluku. The Banten Provincial DPRD has targeted the completion of two draft local regulations, namely the revised Regional Regulation on the 2017-2022 Banten Medium-Term Development Plan and the 
Regional Regulation on Zoning in the Coastal Areas and Small Islands (RZWP3K). This was done after a hearing with a number of relevant stakeholders, which subsequently submitted the Regional Legislative Body to the finalization of the draft in the Plenary Meeting which would later be stipulated and ratified as a Regional Regulation.

One of the most important things that can be used as an inhibiting factor in implementing policies is social, economic and political conditions. The external environment helped drive the success of established public policies. Non-conducive social, economic and political environment can be the culprit of the failure of policy implementation performance. Therefore, efforts to implement policies must also pay attention to the conditions of the external environment. The above understanding explains that the success in implementing the government policy made is how the external environment implementing the policy fully encourages what is the goal of the policy that has been made by the government by taking into account the external environment of the implementing organization and the objectives of the policy.

\section{Conclusion}

After identifying the problem, the implementation of rehabilitation activities was carried out through a number of activities including identification of the causes of damage, identification of the extent of damage, and preparation of rehabilitation plans and the policy objectives were to clean up the coastal area from crude oil spills and to restore mangrove plants. Resources in the implementation of coastal rehabilitation policies are financial resources sourced from the budget of PT. Pertamina and the State Budget through the Ministry of Maritime Affairs and Fisheries, while the human resources involved are officers appointed by Pertamina and the community who will be paid by Pertamina to clean up oil spills. Communication from the implementation of the coastal rehabilitation policy is the Ministry of Maritime Affairs and Fisheries and the Regional Government as the program implementers have communicated to Pertamina to work together to rehabilitate the northern coast of Banten and also to discuss the compensation given to fishermen and surrounding communities.

Based on the characteristics of the implementing agent it is known that the implementer understands well what are the objectives and responsibilities in each task and job that has been given. Regarding the value preferences held by the policy implementing agency based on the results of the study, it can be seen that the value that is used as a reference in implementing the policy is the value of compliance with applicable laws and regulations. Then the social, economic and political conditions that affect coastal rehabilitation policies are the people asking PT. Pertamina to be transparent regarding the YYA-1 well is known to experience operational failure, while the economic conditions that occur due to pollution of the area are expected to occur ecologically and economically because thousands of fishermen are forced to stop forcibly fishing and this causes income to decline, even none. Many fish and shrimp die from oil spills that pollute sea water. Whereas the political condition resulting from pollution of coastal areas is that the Central Government continues to encourage the Provincial Government to immediately complete the regional regulation on zoning plans for coastal areas and small islands as soon as possible. 


\section{References}

[1] Suara newspaper, "Koalisi Masyarakat Desak Pertamina Jujur Soal Kebocoran Minyak di Karawang," Suara.com, 2019.

[2] B. D. Kurniawan, "Implementasi kebijakan sertifikasi guru dalam rangka meningkatkan profesionalitas guru di Kota Yogyakarta,” J. Stud. Pemerintah., vol. 2, no. 2, 2011.

[3] F. Wulandari, "Analisis Kebijakan Pemerintah Dalam Penataan Minimarket Di Kota Palopo." 2015.

[4] B. M. Natalia, "Implementasi Program Zona Air Minum Prima (ZAMP) Untuk Memenuhi Kebutuhan Air Minum Masyarakat (Studi Pada PDAM Kota Malang)," J. Adm. Publik, vol. 2, no. 1, pp. 11-15, 2014.

[5] L. Lusiana, "Implementasi Program Indonesia Pintar (PIP) di Desa Sukomulyo Kecamatan Sepaku Kabupaten Penajam Paser Utara: Studi Kasus di SDN 011 dan SDN 013," J. Adm. Negara, vol. 6, no. 1, pp. 6991-7005, 2017.

[6] D. Wisakti, "Implementasi kebijakan alokasi dana desa di wilayah kecamatan geyer kabupaten grobogan.” program Pascasarjana Universitas Diponegoro, 2008.

[7] W. Nurharjadmo, "Evaluation Implementation Dual System Education Program in Senior Technical High School," Spirit Publik, vol. 4, no. 2, pp. 215-228, 2008. 